\title{
The Action of Nalidixic Acid on Euglena Plastids
}

\author{
By L. EBRINGER \\ Department of Microbiology, Komensky University, Bratislava, Czechoslovakia
}

(Accepted for publication 12 December 1969)

When Euglena gracilis is grown in the presence of some antibiotics (Provasoli, Hutner \& Schatz, 1948; Ebringer, 1962, 1966; Celmer \& Ebringer, 1967), organisms with no chloroplasts are soon produced. These aplastidic organisms can then be isolated and maintained as permanently colourless races. The mechanism of the bleaching action is still in dispute. We have suggested an interaction with plastid DNA or some hereditary apparatus responsible for chloroplast replication (Ebringer, Mego \& Jurášek, 1969). To test this hypothesis, we have examined some antibacterial agents which inhibit DNA synthesis in bacteria or in other organisms. Nalidixic acid inhibits specifically the synthesis of DNA in bacteria (Goss, Deitz \& Cook, 1965 $a, b$; Cook et al. 1966) and exerts a mutagenic effect upon proliferating bacteria (Cook, Goss \& Deitz, 1966). Some other agents which affect DNA synthesis in bacteria also exert a bleaching action on Euglena gracilis (to be published), so the question arises whether nalidixic acid is able to produce permanent colourless races of this organism.

\section{METHODS}

Euglena gracilis, strain $\mathrm{z}$, was used in this study. Cultivation conditions and all methods of evaluation were as previously described (Ebringer et al. 1969). Chloroplasts were counted in samples of exactly 200 organisms. Identification of chloroplasts was made on the presence of a discrete structure containing chlorophyll which showed definite absorption of blue light by fluorescence microscopy. The source of u.v. light used was a mercury lamp (Vorschaltgerat HBO 50, Carl Zeiss, Jena); blue filters nos. BG $3 / 2$, BG $3 / 4$ and BG I2/2 were used and for the eyepiece protecting filter no. GG 9 was employed. This combination of filters gave the advantage that leucoplasts, paramylon grains, cell walls and other details could be distinguished in addition to chloroplasts.

\section{RESULTS}

Nalidixic acid caused the mean number of plastids per organism to decrease gradually until on the fourth day of cultivation the organisms almost completely lacked chloroplasts (Table I). In the control culture without nalidixic acid the mean number of plastids per organism decreased slightly on the first day, but the number returned to the original value of about 8 .

After treatment with nalidixic acid the chlorophyll content per $10^{7}$ organisms gradually declined and on the fourth day of cultivation only traces remained (Table 2), but in the control culture the chlorophyll content increased continuously so that on the fourth day it was around 20 times higher than in a parallel drug-treated culture. 
Table I. Chloroplast counts per organism at intervals during growth of Euglena gracilis with $500 \mu \mathrm{g} . / \mathrm{ml}$. of nalidixic acid and in control without the drug. Initial $\mathrm{pH} 7 \cdot 8$

\begin{tabular}{|c|c|c|c|c|c|c|c|c|}
\hline \multirow{3}{*}{$\begin{array}{l}\text { No. of } \\
\text { plastids }\end{array}$} & \multicolumn{8}{|c|}{ Frequency (no. of organisms) } \\
\hline & \multicolumn{4}{|c|}{ Nalidixic acid } & \multicolumn{4}{|c|}{ Control } \\
\hline & Day I & Day 2 & Day 3 & Day 4 & Day I & Day 2 & Day 3 & Day 4 \\
\hline 0 & - & I & 85 & 199 & - & - & - & - \\
\hline I & - & 4 & 24 & - & - & - & - & - \\
\hline 2 & - & 28 & 43 & I & - & 1 & - & - \\
\hline 3 & I & 67 & 31 & - & 3 & - & - & - \\
\hline 4 & 36 & 67 & IO & - & 19 & 18 & 14 & 2 \\
\hline 5 & 71 & 30 & 5 & - & 62 & 45 & 22 & 6 \\
\hline 6 & 38 & 2 & - & - & 46 & 47 & 29 & 23 \\
\hline 7 & 42 & I & 2 & - & $4 \mathrm{I}$ & 56 & 42 & 44 \\
\hline 8 & II & - & - & - & 14 & 24 & $4 \mathrm{I}$ & 42 \\
\hline 9 & - & - & - & - & 9 & 9 & 20 & 27 \\
\hline 10 & I & - & - & - & 3 & - & I2 & 19 \\
\hline I I & - & - & - & - & I & - & 8 & 12 \\
\hline 12 & - & - & - & - & I & - & 7 & 13 \\
\hline I3 & - & - & - & - & I & - & 4 & 4 \\
\hline 14 & - & - & - & - & - & - & - & 2 \\
\hline 15 & - & - & - & - & - & - & I & 5 \\
\hline 18 & - & - & - & - & - & - & - & I \\
\hline $\begin{array}{c}\text { Total } \\
\text { organisms } \\
\text { counted }\end{array}$ & 200 & 200 & 200 & 200 & 200 & 200 & 200 & 200 \\
\hline $\begin{array}{l}\text { Plastids } \\
\text { per } \\
\text { organism }\end{array}$ & & & & & & & & \\
\hline Range & $3-10$ & $0 \rightarrow 7$ & $0-7$ & $0-2$ & $3-13$ & $2-9$ & $4-15$ & $4-18$ \\
\hline Mean & $5 \cdot 5$ & 3.4 & $\mathrm{I} \cdot 4$ & 0.01 & 5.5 & $6 \cdot 2$ & $7 \cdot 5$ & $8 \cdot 5$ \\
\hline
\end{tabular}

Table 2. Concentration of organisms, chlorophyll content and percentage of permanently bleached colonies after treatment with nalidixic acid at $500 \mu \mathrm{g} . / \mathrm{ml}$. in medium of initial pH 7.8. '\% bleached colonies' refers to the \% colonies which were bleached after washing the organisms and plating on solid drug-free medium. Colonies were counted on the gth day after plating

\begin{tabular}{|c|c|c|c|c|c|c|}
\hline \multirow[b]{2}{*}{ Day } & \multicolumn{2}{|c|}{$\begin{array}{l}\text { Number of cells } \\
\times \mathrm{IO}^{3} \text { per } \mathrm{ml} .\end{array}$} & \multicolumn{2}{|c|}{$\begin{array}{l}\mu \mathrm{g} \text {. chlorophyll } \\
\text { per } \mathrm{I}^{7} \text { cells }\end{array}$} & \multicolumn{2}{|c|}{$\begin{array}{l}\% \text { bleached } \\
\text { colonies }\end{array}$} \\
\hline & Test & Control & Test & Control & Test & Control \\
\hline I & 93 & 86 & 20 & 26 & 17 & 0 \\
\hline 2 & I94 & 184 & 19 & 28 & 86 & 0 \\
\hline 3 & 493 & 501 & 13 & 56 & 92 & 0 \\
\hline 4 & 1388 & II 75 & 8 & I 58 & 96 & 0 \\
\hline
\end{tabular}

Nalidixic acid required more than 4 days to produce $100 \%$ bleached colonies at 500 $\mu \mathrm{g} . / \mathrm{ml}$. and at an initial $\mathrm{pH}$ of $7 \cdot 8$. In a medium with an initial $\mathrm{pH}$ of $6 \cdot 0$, the bleaching action of nalidixic acid was weaker: higher concentrations of drug and longer periods of exposure were required to produce $100 \%$ bleaching. Concentrations of nalidixic acid lower than $500 \mu \mathrm{g} . / \mathrm{ml}$. bleached only a certain number of organisms within 4 days. 
To obtain $100 \%$ bleaching with lower doses it was necessary to prolong the cultivation time.

During cultivation in the presence of nalidixic acid, the plastids became increasingly abnormal in appearance, smaller and less dense (Pl. I, fig. I to 4). By the third day the number of plastids was definitely decreased and they were clumped in the centre; on the fourth day all traces of plastids had disappeared. In the control cells (Pl. I, fig. 5) on the fourth day of cultivation fully developed chloroplasts could be counted.

\section{DISCUSSION}

Nalidixic acid, an inhibitor of bacterial DNA synthesis, apparently blocks replication of plastids without concomitant blocking of cell division. After about six divisions in the presence of the drug the organisms become aplastidic. The weaker effect of nalidixic acid at $\mathrm{pH} 6.0$ is similar to what has been found in the antibacterial action of this drug. Fortunately Euglena gracilis grows at the same rate in media of widely different $\mathrm{pH}$ values. Like other antibacterial agents, nalidixic acid bleaches only dividing organisms; non-growing cultures are not bleached. This finding correlates well with the antibacterial activity of nalidixic acid, which is lethal only for proliferating cultures of bacteria (Goss, Deitz \& Cook, 1965). The drug does not inhibit multiplication of $E$. gracilis. It is relatively non-toxic to euglenas and is very well tolerated by laboratory animals and man. These factors favour the use of nalidixic acid as a bleaching agent for, in order to be effective, such a substance must be less toxic for the whole organism than for the plastids.

It has been suggested that plastids originated from exogenous photosynthetic bacteria or blue-green algae which became symbionts in eukaryotic cells (Mereschkowski, 1905). This is why we decided to compare the actions of various antibacterial drugs against plastids of Euglena gracilis. All inhibitors of bacterial DNA synthesis (rubiflavin, sarkomycin, edeine, porfiromycin, anthramycin, novobiocin, streptonigrin and nalidixic acid) inhibit replication of plastids so that after several cell divisions bleached organisms are obtained (to be published). We emphasize that this loss of plastids is permanent and hereditary. Mutants obtained by nalidixic acid are white and permanently heterotrophic. Inhibitors of protein and RNA synthesis often produce temporary loss of chlorophyll but, with the exception of streptomycin and erythromycin, this effect is never permanent (to be published). We consider this indirect evidence that streptomycinoid antibiotics and the macrolides produce bleaching by an interaction with plastid DNA synthesis. Stern, Barner \& Cohen (I966) showed that streptomycin does in fact inhibit DNA replication in bacteria and consider this process to be the primary site of action of streptomycin. Alteration of DNA appears to be a more reasonable explanation of permanent hereditary changes than interference with RNA or protein synthesis. Studies of the effect of these drugs on isolated Euglena plastids might help to clarify this question.

Nalidixic acid was a generous gift of Dr J. A. Abel, The Winthrop Products Company, Surbiton, England, who also co-operated on the preparation of this paper. Miss Gabriela Smutná provided technical assistance. 


\section{REFERENCES}

Celmer, W. D. \& Ebringer, L. (1967). Effects of certain $O$-acyl derivatives of oleandomycin and erythromycin on chloroplasts of Euglena gracilis. Journal of Protozoology 14, 263.

Cook, T. M., Goss, W. A. \& Derrz, W. H. (1966). Mechanism of action of nalidixic acid on Escherichia coli. V. Possible mutagenic effect. Journal of Bacteriology 9r, 780.

Cook, T. M., Brown, K. G., Boyle, J. V. \& Goss, W. A. (1966). Bactericidal action of nalidixic acid on Bacillus subtilis. Journal of Bacteriology 92, 1510.

EBRINGER, L. (1962). Erythromycin and streptomycin-like antibiotics as bleaching factors for Euglena gracilis. Naturwissenschaften 49, 334.

EBRINGER, L. (1966). Antibiotics and apochlorosis. I. Macrolide antibiotics-their common molecular structure responsible for bleaching of Euglena gracilis. Folia Microbiologica, Praha Ir, 379

EBRINGER, L., MeGo, J. L. \& JURÁšEK, A. (1969). Mitomycins and the bleaching of Euglena gracilis. Archiv für Mikrobiologie 64, 229.

Ebringer, L., Mego, J. L., JuRÁšEK, A. \& KadA, R. (1969). The action of streptomycins on the chloroplast system of Euglena gracilis. Journal of General Microbiology 59, 203.

Goss, W. A., DerTz, W. H. \& Cook, T. M. (1965 a). Mechanism of action of nalidixic acid on Escherichia coli. Journal of Bacteriology 88, I 12.

Goss, W. A., Dertz, W. H. \& Cook, T. M. (1965 b). Mechanism of action of nalidixic acid on Escherichia coli. II. Inhibition of deoxyribonucleic acid synthesis. Journal of Bacteriology 89, 1068.

MeresChKowsKI, C. (1905). Über Natur und Ursprung der Chromatophoren im Pflanzenreiche. Biologisches Zentralblatt 25, 593.

Provasoli, L., Hutner, S. H. \& Schatz, A. (1948). Streptomycin-induced chlorophyll-less races of Euglena. Proceedings of the Society for Experimental Biology and Medicine 69, 279.

Stern, J. L., BARNer, H. D. \& CoHen, S. S. (1966). The lethality of streptomycin and the stimulation of RNA synthesis in the absence of protein synthesis. Journal of Molecular Biology 17, 188.

\section{EXPLANATION OF PLATE}

Fig. I-4. Euglena gracilis on the first, second, third and fourth day after addition of nalidixic acid.

Fig. 5. Control Euglena gracilis on the fourth day of cultivation on the drug-free medium. 
Journal of General Microbiology, Vol. 6I, No. I

Plate I
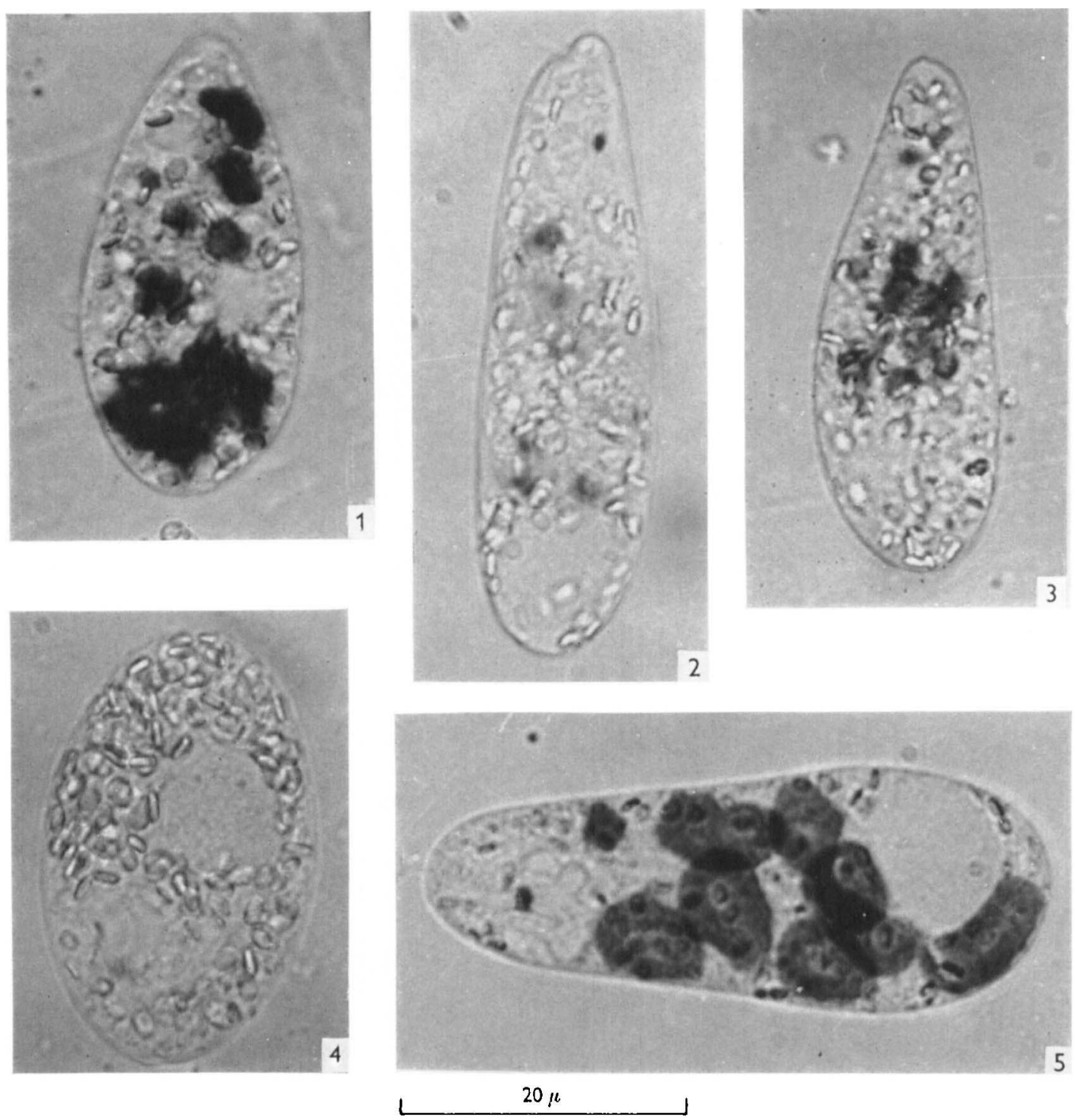